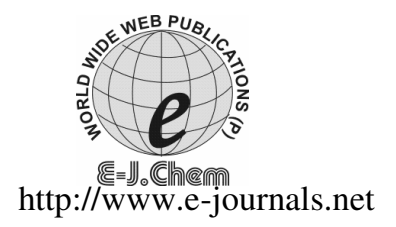

ISSN: 0973-4945; CODEN ECJHAO

E-Journal of Chemistry

2011, 8(4), 1606-1613

\title{
Cloud Point Extraction of Toxic Reactive Black 5 Dye from Water Samples Using Triton X-100 as Nonionic Surfactant
}

\author{
RAZIYEH MOUSAVI and FARZIN NEKOUEI* \\ Department of Chemistry, Gachsaran Branch, \\ Islamic Azad University, Gachsaran, Iran \\ *Young Researchers Club, Gachsaran Branch, \\ Islamic Azad University, Gachsaran, Iran \\ f.nekouei@hotmail.com
}

Received 16 December 2010; Accepted 24 January 2011

\begin{abstract}
A surfactant mediated cloud point extraction (CPE) procedure has been developed to remove color from wastewater containing reactive black 5 , using triton $\mathrm{x}-100(\mathrm{TX}-100)$ as non-ionic surfactant. The effects of the concentration of the surfactant, $\mathrm{pH}$, temperature and salt concentration on the different concentrations of dye have been studied and optimum conditions were obtained for the removal of reactive black 5 (RB 5). The concentration of RB 5 in the dilute phase was measured using UV-Vis spectrophotometer. It was found that the separation of phases was complete and the recovery of RB 5 was very effective in the presence of $\mathrm{NaCl}$ as an electrolyte. The results showed that up to $600 \mathrm{mg} \mathrm{L}^{-1}$ of RB 5 can quantitatively be removed (>97\%) by cloud point extraction procedure in a single extraction using optimum conditions.
\end{abstract}

Keywords: Reactive black 5 dye, Triton x-100, Cloud point extraction, Water samples

\section{Introduction}

The large quantity of organic colored wastewaters generated by textile, paper, plastic, leather, food and mineral processing industries has become a significant environmental problem. It is estimated that $1-15 \%$ of the dye is lost during dyeing and finishing processes and is released into wastewaters. The textile industry utilizes about 10,000 dyes and pigments ${ }^{1}$. Strong color of the wastewater effluents is particularly troublesome because of its negative visual impact ${ }^{2}$. Dye bath effluents impart color to receiving streams and affect its aesthetic value. Color interferes with penetration of sunlight into waters, retards photosynthes is, inhibits the growth of aquatic biota and interferes with gas solubility in water 
bodies. Furthermore, dye effluent may contain chemicals, which are toxic, carcinogenic, mutagenic or teratogenic in various microbiologic, fish species ${ }^{3}$. Reactive black 5 is a diazo dye and widely used in textile, paper and leather industries. This dye is also extensively used in cosmetics, food additives, ink and paint. The structure of the dye is shown in Figure 1. Conventionally, biological, chemical and physical methods have been employed for dye removal, but the biological techniques have not been very successful due to the nonbiodegradable nature of most dyes ${ }^{4}$. There are many processes to remove dyes from colored effluents such as adsorption, precipitation, chemical degradation, photodegradation, biodegradation, chemical coagulation and electrocoagulation. When chemical coagulation is used to treat dyeing wastewater, the pollution may be caused by chemical substance added at a high concentration ${ }^{3}$. The decomposition of the chromospheres in dyes can be achieved by injecting a strong oxidizing agent such as ozone. However, a large dose of ozone, which is not economically feasible, is usually required for decolorization due to the significant amount of auxiliary chemicals ${ }^{5}$. The adsorption process is one of the effective methods used to remove dyes from aqueous solution. Activated carbon is the most widely used adsorbent for dye removal, but it is too expensive ${ }^{6}$. Photooxidation by $\mathrm{UV} / \mathrm{H}_{2} \mathrm{O}_{2}$ or $\mathrm{UV} / \mathrm{TiO}_{2}$ and Fenton oxidation needs additional chemicals $\mathrm{s}^{7-13}$ and therefore causes a secondary pollution. Electrochemical process is effective ${ }^{14}$. Biodegradation process is cheaper than other methods, it is less effective because of the toxicity of dyes that has an inhibiting effect on the bacterial development ${ }^{15}$. In the last decade, increasing interest on the use of aqueous micellar solution has been found in the field of separation science ${ }^{16}$. The cloud point extraction (CPE) technique has also been used as a method for removal of dyes. The removal of color from wastewater containing Congo $\operatorname{red}^{17}$ and $\operatorname{eosin}^{18}$ has been performed by surfactant mediated cloud point extraction in batch mode using triton $\mathrm{x}-100$ as non-ionic surfactant. Hence, cloud point extraction (CPE) as an extraction method was developed to overcome the drawbacks of conventional decolorization technologies.

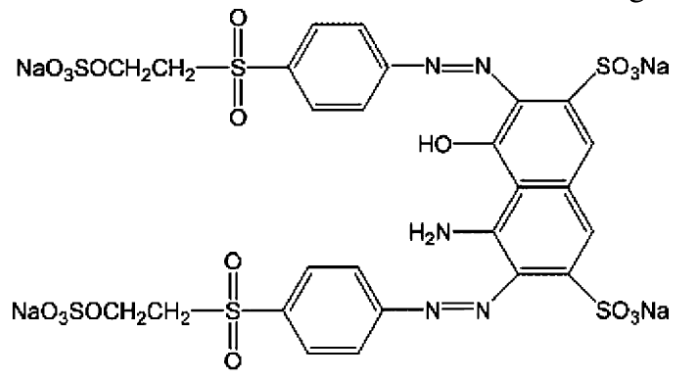

Figure 1. Reactive black 5 structure. RB5 class: diazo; reactive group: sulfatoethylsulfone; natural $\mathrm{pH}: 5.8 ; \lambda_{\max }$ (visible): $591 \mathrm{~nm}$; molecular weight: $991.8 \mathrm{~g} \mathrm{~mol}^{-1}$

In this work, we have adopted cloud point extraction technique for the removal of RB 5 from wastewater using triton $\mathrm{x}-100$ as non-ionic surfactant. The effect of temperature, $\mathrm{pH}$, concentrations of surfactant, dye and salt on the cloud point extraction of dye has been studied in order to establish optimum conditions.

\section{Experimental}

A Shimadzu model 160A UV-Vis spectrophotometer was used for recording absorption spectra and absorbance measurements using $1 \mathrm{~cm}$ glass cells. A Metrohm digital $\mathrm{pH}$ meter model 691 with a combined glass electrode measured the $\mathrm{pH}$. A thermostat bath model 
Colora maintained at the desired temperature was used for the cloud point temperature (CPT) experiments. A 30 E 148 Sheme fan or Hettich centrifuge was used to accelerate the phase separation process.

All chemicals used were of analytical grade and doubled distilled water was used throughout. A stock solution of $600 \mathrm{mg} \mathrm{L}^{-1}$ of RB 5 was prepared by dissolving $0.150 \mathrm{~g}$ of the reagent (Alvan Sabet Company, Iran) in water and diluting to $250 \mathrm{~mL}$ in a volumetric flask. The desired concentrations were obtained by successive dilutions. A measure of $0.3 \mathrm{~mol} \mathrm{~L}^{-1}$ of triton $\mathrm{x}-100$ (Aldrich) was prepared by dissolving $48.52 \mathrm{~g}$ in water and diluting to $250 \mathrm{~mL}$ in a volumetric flask. A $2.0 \mathrm{~mol} \mathrm{~L}^{-1}$ solution of sodium chloride was prepared by dissolving $11.68 \mathrm{~g}$ of $\mathrm{NaCl}$ (Merck) in water and diluting to $100 \mathrm{~mL}$ in a volumetric flask. A $2.0 \mathrm{~mol} \mathrm{\textrm {L } ^ { - 1 }}$ solution of potassium chloride was prepared by dissolving $14.91 \mathrm{~g}$ of $\mathrm{KCl}$ (Merck) in water and diluting to $100 \mathrm{~mL}$ in a volumetric flask.

Britton-robinson buffer solution in the $\mathrm{pH}$ range of 4 was made by mixing phosphoric acid $0.04 \mathrm{~mol} \mathrm{~L}^{-1}$, acetic acid $0.04 \mathrm{~mol} \mathrm{~L}^{-1}$ and boric acid $0.04 \mathrm{~mol} \mathrm{~L}^{-1}$ with appropriate volumes of $0.2 \mathrm{~mol} \mathrm{~L}^{-1}$ solution of sodium hydroxide ${ }^{19}$.

\section{General removal procedure}

An aliquot of the RB 5 solution, $10 \mathrm{~mL}$ of $2.0 \mathrm{~mol} \mathrm{~L}^{-1}$ of $\mathrm{NaCl}, 20 \mathrm{~mL}$ of $0.3 \mathrm{~mol} \mathrm{~L}^{-1}$ of triton $\mathrm{x}-100$ and $7 \mathrm{~mL}$ of Britton Robinson buffer were added to a $50 \mathrm{~mL}$ volumetric flask and diluted to the mark with water. The resultant solution was transferred to a $50 \mathrm{~mL}$ tube and equilibrated at $65{ }^{\circ} \mathrm{C}$ in a thermostat bath for $30 \mathrm{~min}$. Separation of the phases was achieved by centrifugation at $3500 \mathrm{rpm}$ for $10 \mathrm{~min}$. The whole system was cooled in an icebath so for $10 \mathrm{~min}$ that the surfactant rich phase would regain its viscosity. In this way, the bulk dilute phase was easily decanted. The concentration of RB 5 in the dilute phase was measured by spectrophotometeric method.

\section{Analysis of dye in dilute phase}

A series of RB 5 solutions with different concentrations were prepared and their absorbance was measured at $591 \mathrm{~nm}$. A linear calibration graph was obtained in the range of 5.0-50 mg L $\mathrm{L}^{-1}$ of RB 5 in aqueous solution. The equation of the regression line was $A=0.0208 \mathrm{C}+0.0029$ with a correlation coefficient of 0.9998 ( $\mathrm{C}$ is concentration of RB 5 as $\left.\mathrm{mg} \mathrm{L}^{-1}\right)$. This calibration equation was used to determine RB 5 concentration in dilute aqueous phase solution after removal of the dye by CPE in order to calculate the extraction efficiency.

\section{Results and Discussion}

For cloud point extraction, the efficiency of extraction is defined below:

Efficiency of extraction $=\left(1-\mathrm{C}_{\mathrm{d}} / \mathrm{C}_{0}\right) \times 100$

In which $\mathrm{C}_{0}$ and $\mathrm{C}_{\mathrm{d}}$ are the initial and dilute phase concentration of RB 5, respectively. The absorption spectra of RB 5 showed a maximum absorption band at $591 \mathrm{~nm}$. Therefore, all the measurements were carried out at this wavelength. The effects of various operating conditions on the extent of dye separation have been investigated and the optimum concentrations have been established for CPE.

\section{Effect of initial $\mathrm{pH}$}

For this study, the effect of a pH range of 1-7 on the CPE of 20, 50 and $100 \mathrm{mg} \mathrm{L}^{-1}$ of RB 5 was investigated. As can be seen in Figure 2, maximum efficiency was obtained at $\mathrm{pH} 2$. Therefore, this $\mathrm{pH}$ was chosen for further work. Different buffer systems with $\mathrm{pH} 2$ were 
examined and Britton-Robinson buffer was selected as the optimum for subsequent experiments because it did not change the extraction efficiency of the solution after CPE. The effect of different volumes of Britton-Robinson buffer solution $(2-8 \mathrm{~mL})$ was investigated. The results showed that the extraction efficiency of the solution increased with buffer volume up to $6 \mathrm{~mL}$ and remained constant above that. Thus, $7 \mathrm{~mL}$ of Britton-Robinson buffer $\mathrm{pH} 2$ was added to the sample solutions to maintain the $\mathrm{pH}$ at 2 .

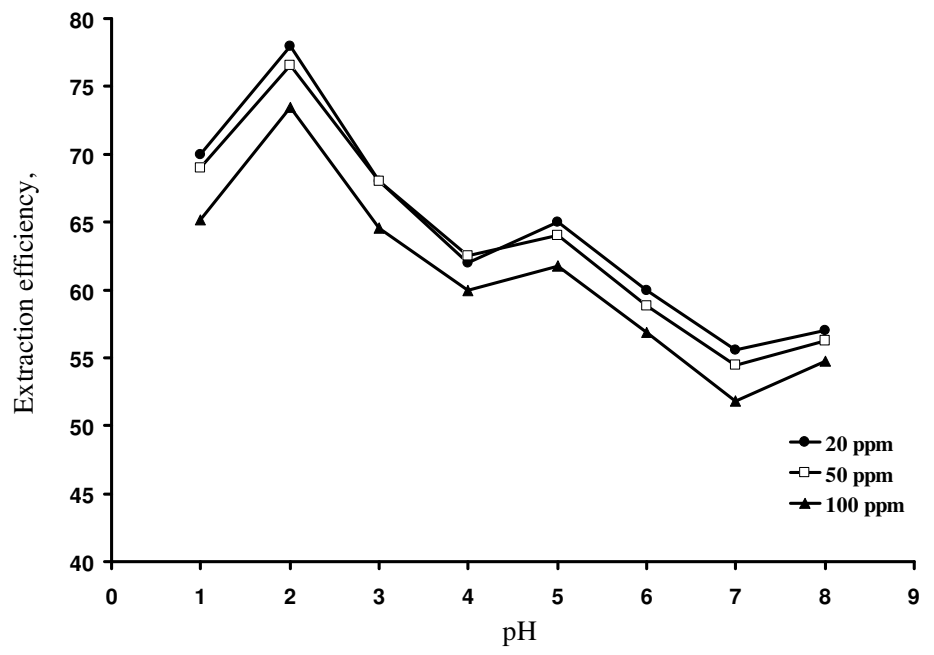

Figure 2. Effect of $\mathrm{pH}$ on removal of reactive black 5 (Conditions: $50 \mathrm{~mL}$ of solution containing different concentration of dye (20,50 and $100 \mathrm{ppm}), 0.4 \mathrm{M}$ of $\mathrm{NaCl}$ and $0.12 \mathrm{M}$ of triton $x-100$, equilibration temp $65{ }^{\circ} \mathrm{C}$ and equilibration time $30 \mathrm{~min}$, centrifuge time $10 \mathrm{~min}$ and centrifuge rates $3500 \mathrm{rpm})$.

\section{Effect of electrolyte concentration}

It has been shown that the presence of electrolytes can change the cloud point (CP) in different ways ${ }^{20}$. Salting-out electrolytes such as $\mathrm{NaCl}$ and $\mathrm{KCl}$ decrease the cloud point temperature, even by $30^{\circ} \mathrm{C}$. They can promote the dehydration of the ethoxy groups on the outer surface of the micelles, enhancing the micellar concentration leading to solubilization of more dye and resulting in a more efficient extraction ${ }^{21}$. Thus, the separation of the surfactant-rich phase can be obtained at lower temperatures, which is very important from practical point of view. Therefore, the effect of both potassium chloride and sodium chloride as electrolytes was studied. The results showed that when concentration of $\mathrm{KCl}$ or $\mathrm{NaCl}$ is increased, the extraction efficiency of RB 5 was increased only by few percent but both electrolytes decreased the cloud point temperature and our further experiments showed that less triton $\mathrm{x}-100$ is consumed when using $\mathrm{NaCl}$ as electrolyte. Thus, for this reason and because $\mathrm{NaCl}$ is more economical it was chosen as an electrolyte for further studies.

\section{Effect of triton $x$-100 concentration}

Several non-ionic surfactant including triton x-114, triton x-100 and PONPE 7.5 were tested for performing of CPE. Among them triton $\mathrm{x}-100$ was chosen because of its higher extraction efficiency as well as its appropriate cloud point temperature as compared with other tested surfactants. The effect of the triton $\mathrm{x}-100$ concentration on the removal of RB 5 is shown in Figure 3. As it is observed at a fixed temperature and feed dye concentration, the extraction efficiency of dye increases with surfactant concentration. The concentration of 
the micelles increases with surfactant concentration, resulting in more solubilization of dyes in the micelles. Since the surfactant concentration in the dilute phase remains around critical micelle concentration (CMC), the surfactant concentration along with the solubilized dye in the coacervate phase increases to maintain the material balance. Therefore, the extraction efficiency of dye increases with surfactant concentration. Quantitative removal of RB $5(>97 \%)$ was obtained when minimum $0.108 \mathrm{~mol} \mathrm{~L}^{-1}$ of triton $\mathrm{x}-100$ was used. The optimum surfactant concentration of $0.12 \mathrm{~mol} \mathrm{~L}^{-1}$ of triton $\mathrm{x}-100$ was selected in order to achieve the optimal analytical signal in conjunction with the highest possible extraction efficiency.

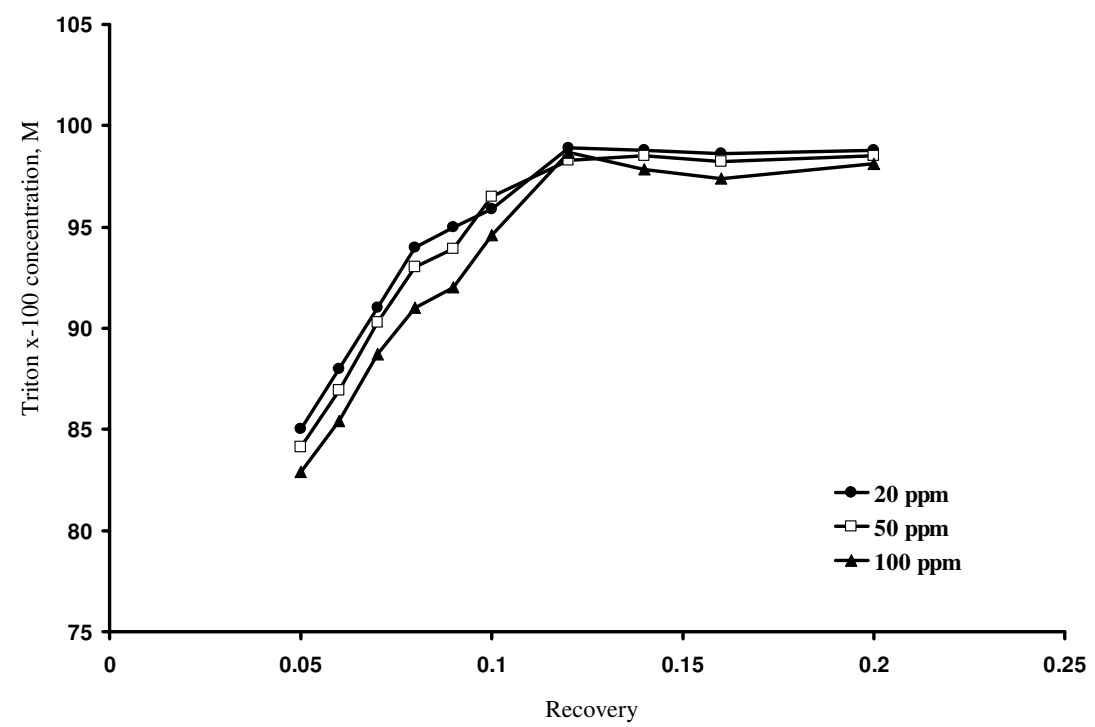

Figure 3. Effect of triton $\mathrm{x}-100$ on removal of reactive black 5 (Conditions: $50 \mathrm{~mL}$ of solution containing different concentration of dye (20,50 and $100 \mathrm{ppm}), 0.4 \mathrm{M}$ of $\mathrm{NaCl}$ and $\mathrm{pH} 2$, equilibration temp $65^{\circ} \mathrm{C}$ and equilibration time $30 \mathrm{~min}$, centrifuge time $10 \mathrm{~min}$ and centrifuge rates $3500 \mathrm{rpm}$ ).

\section{Effect of temperature}

The solubilization capability of the micellar solution increases with temperature leading to an increase in the dye extraction. Therefore, the effect of operating temperature on the removal of dye was investigated. The results of the effects of the operating temperature on the extraction efficiency of dye indicated that the extraction of dye increases with temperature at different concentration of the dye $\left(20,50\right.$ and $\left.100 \mathrm{mg} \mathrm{L}^{-1}\right)$ up to a temperature of $65{ }^{\circ} \mathrm{C}$ and it is constant above that. Thus, temperature of $65{ }^{\circ} \mathrm{C}$ was used in further studies.

\section{Effect of equilibration time}

The dependence of extraction efficiency upon equilibration time was studied for a time interval of 5-30 min. Quantitative extraction efficiency values ( $>97 \%)$ for different concentrations of the dye $\left(20,50\right.$ and $\left.100 \mathrm{mg} \mathrm{L}^{-1}\right)$ were obtained after $30 \mathrm{~min}$. An equilibration time of $30 \mathrm{~min}$ was chosen as an optimum value. The equilibration time required in the proposed cloud point procedure is only $30 \mathrm{~min}$ while the equilibration time (incubation time) required for other procedures is higher ${ }^{22-25}$. 


\section{Effect of centrifuge time and rates}

It is often required to preconcentrate trace amounts of dye with high efficiency in a short time. The results indicate that centrifugation for $10 \mathrm{~min}$ at $3500 \mathrm{rpm}$ and cooling for $10 \mathrm{~min}$ in an ice-bath lead to the highest recovery of RB 5 dye.

\section{Effect of initial dye concentration}

The effect of initial dye concentration on the extraction efficiency using above optimum concentrations was investigated. The results presented in Table 1 show that for dye concentration of $5 \mathrm{mg} \mathrm{L}^{-1} 100 \%$ extraction efficiency is possible with triton $\mathrm{x}-100$ concentration of $0.120 \mathrm{~mol} \mathrm{~L}^{-1}$. For concentrations up to $600 \mathrm{mg} \mathrm{L}^{-1}$, reactive black 5 quantitative removal $(>97 \%)$ is achieved by CPE procedure in a single extraction which is higher than some of the previously reported methods ${ }^{24-26}$.

Table 1. Effect of initial dye concentration on the CPE efficiency of reactive black 5

\begin{tabular}{cc}
\hline Concentration, $\mathrm{mg} \mathrm{L}^{-1}$ efficiency $\%$ & ${ }^{\mathrm{a}} \mathrm{CPE}$ \\
\hline 5 & 100 \\
10 & 98.3 \\
20 & 98.9 \\
50 & 98.3 \\
100 & 98.7 \\
250 & 97.9 \\
400 & 97.5 \\
600 & 97.1 \\
\hline${ }^{a}$ CPE: Cloud point extraction &
\end{tabular}

The extraction efficiency decreases with increasing dye concentration at constant triton $\mathrm{x}-100$ concentration. As can be observed in Figure 3, the extraction efficiency can be further improved ( $>98 \%$ ) by increasing triton $\mathrm{x}-100$ concentration to $0.16 \mathrm{~mol} \mathrm{~L}^{-1}$. The dye uptake in this study was $600 \mathrm{mg} \mathrm{L}^{-1}$, which is higher than some of the previously reported methods ${ }^{22-24,26-28}$.

\section{Interference studies}

The effect of various ions as potential interference on the removal of RB 5 was investigated. Known concentrations of potential interfering ions were added to a solution containing $20 \mathrm{mg} \mathrm{L}^{-1}$ of RB 5 and the dilute phase solution was analyzed by the proposed method. The tolerance limit of each foreign ion substance was taken as largest concentrations yielding an error of less $\pm 5 \%$. The results presented in Table 2 show that very good selectivity is achieved. The interference of direct red, direct yellow 12, golden yellow and reactive black 22 as dye was also studied.

\section{Application to real samples}

In order to test the reliability of the proposed removal methodology, it was applied to the removal of concentrations of reactive black 5 from domestic waste water, river water and industrial water samples. For this purpose, $15 \mathrm{~mL}$ of each of the samples was treated under the general procedure. Spiking RB 5 to the samples performed the validity of the procedure. The results presented in Table 3 show that good extraction efficiencies are obtained for the removal of RB 5 spiked to river water, industrial water and domestic waste water samples. 
Table 2. The effect of foreign species on the determination of $20 \mathrm{mg} \mathrm{L}^{-1}$ of RB 12

\begin{tabular}{cc}
\hline Foreign species tolerance ratio, w/w & \\
\hline $\mathrm{Na}^{+}, \mathrm{Cd}^{2+}, \mathrm{Mg}^{2+}, \mathrm{Ca}^{2+}, \mathrm{NH}_{4}^{+}, \mathrm{I}^{-}, \mathrm{Bi}^{+}$, & \\
$\mathrm{NO}_{2}^{-}, \mathrm{Br}^{-}, \mathrm{F}^{-}, \mathrm{HPO}_{4}^{2-}, \mathrm{Zn}^{2+}, \mathrm{SO}_{3}^{2-}, \mathrm{Mn}^{2+}$ & 1500 \\
$\mathrm{Ag}^{+}, \mathrm{Sr}^{2+}, \mathrm{CH}_{3} \mathrm{COO}^{-}, \mathrm{Li}^{+}$ & 1000 \\
$\mathrm{~Pb}^{2+}, \mathrm{SCN}^{-}, \mathrm{Ba}^{2+}$ & 800 \\
$\mathrm{Cu}^{2+}, \mathrm{CO}^{2+}, \mathrm{ClO}_{4}^{-}$ & 600 \\
$\mathrm{NO}_{3}^{-}, \mathrm{Al}^{3+}$ & 300 \\
$\mathrm{Fe}^{2+}$ & 150 \\
Direct yellow 12 (dye) & 100 \\
Direct red (dye) & 75 \\
Golden yellow (dye) & 25 \\
Reactive black 22 (dye) &
\end{tabular}

Table 3. Removal of reactive black 5 in spiked water samples

\begin{tabular}{ccc}
\hline Sample & $\begin{array}{c}\text { Reactive black 5 } \\
\text { added mg L }\end{array}$ & $\begin{array}{c}\text { Extraction } \\
\text { efficiency }\end{array}$ \\
\hline Industrial $\%$
\end{tabular}

\section{Conclusion}

$$
{ }^{a} x \pm t s / \text { N } \text { at } 95 \% \text { confidence }(n=4),(t=3.18)
$$

Cloud point extraction was successfully applied to remove reactive black 5 from wastewater using triton $\mathrm{x}-100$ as a non-ionic surfactant. The extraction efficiency increased with temperature, surfactant and salt concentrations. From the experimental results, it was observed that for dye concentrations 1-600 $\mathrm{mg} \mathrm{L}^{-1}$, quantitative recoveries $(>97 \%)$ is obtained in a single extraction. Triton $x-100$ is environmental friendly, only small amounts is used and can be recovered from the system by a simple extraction. The experimental requirements (additional chemicals, time and preparation of material) are better than some of the previously reported methods ${ }^{5,7,9,13,29}$ for the removal of RB 5. The cloud point extraction procedure described above is straightforward while some of the previously reported methods require pretreatments with chemical compounds for long times. Moreover, cloud point extraction strategy can easily be adopted for large-scale samples.

\section{Acknowledgment}

The authors wish to thank Islamic Azad University, Gachsaran branch, for financial support of this work.

\section{References}

1. Daneshvar N, Oladegaragoze A and Djafarzadeh N, J Hazard Mater., 2006, B129, 116-122. 
2 Barrera-Díaz C, Ureña-Nuñez F, Campos E, Palomar-Pardavé M and Romero-Romo M, Radiat Phys Chem., 2003, 67, 657-663.

3 Daneshvar N, Ashassi-Sorkhabi H and Tizpar A, Sep Purif Technol., 2003, 31(2), 153-162.

4 Golder A K, Hridaya N, Samanta A N and Ray S, J Hazard Mater., 2005, B127, 134-140.

5 Song S, He Z, Qiu J, Xu L and Chen, J Sep Purif Technol., 2007, 55, 238-245.

6 Ozacar M and Sengil I A, Bioresour Technol., 2005, 96(7), 791-795.

7 Aguedacha A, Brosillonb S, Morvanb J and Lhadi E K, Appl Catal., 2005, B Environ 57, 55.

8 Tang W Z and An H, Chemosphere, 1995, 31, 4157.

$9 \quad$ Tang C and Chen V, Water Res., 2004, 38(11), 2775-2781.

10 Bali U, Çatalkaya E and Sengül F, J Hazard Mater., 2004, B114, 159-166.

11 Daneshvar N, Salari D and Khataee A R, J Photochem Photobiol., 2003, A Chem. 157, 111-116.

12 Meriç S, Kaptan D and Ölmez T, Chemosphere, 2004, 54(3), 435-441.

13 Lucas M S and Peres J A, Dyes Pigments, 2006, 71, 235-243.

14 Cerón-Rivera M, Dávila-Jiménez M M and Elizalde-González M P, Chemosphere, 2004, 55(1), 1-10.

15 Işık M and Sponza D T, Chemosphere, 2004, 55, 119-128.

16 Scamehorn J F and Harwell H J, Surfactant Based Separation Processes; Marcel Dekker Inc, New York, 1989, 139.

17 Purkait M K, Vijay S S, Dasgupta S and De S, Dyes Pigments, 2004, 63, 151-159.

18 Purkait M K, Banerjee S, Dasgupta S and De S, Water Res., 2005, 39(16), 3885-3890.

19 Britton H T K and Robinson R A, J Chem Soc., 1931, 458, 1456-1462.

20 Coelho L M and Arruda M A Z, Spectrochim Acta, 2005, B60, 743.

21 Paleologos E K, Giokasm D L and Karayannis M I, Trends Analyt Chem., 2005, 24, 426-436.

22 Osma J F, Saravia V, Toca-Herrera J L and Couto S R, J Hazard Mater., 2007, 147, 900-905.

23 Greluk M and Hubicki Z, Chem Eng J., 2010, 162, 919-926.

24 Murugesan K, Dhamija A, Nam I H, Kim Y M and Chang Y S, Dyes Pigments, 2007, 75, 176-184.

25 Wang H, Zheng X W, Su J Q, Tian Y, Xiong X J and Zheng T L, J Hazard Mater., 2009, 171(1-3), 654-659.

26 Entezari M H, Sharif Al-Hoseini Z and Ashraf N, Ultrason Sonochem., 2008, 15, 433-437.

27 Lucas M S and Peres J A, Dyes Pigments, 2007, 74, 622.

28 Mazmanci M A and Üuyayar A, Process Biochem., 2005, 40(1), 337-342.

29 Colindres P, Madeira H Y and Reguera E, Desalination, 2010, 258, 154-158. 


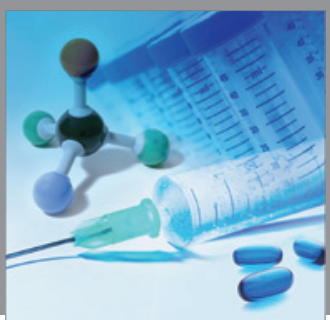

International Journal of

Medicinal Chemistry

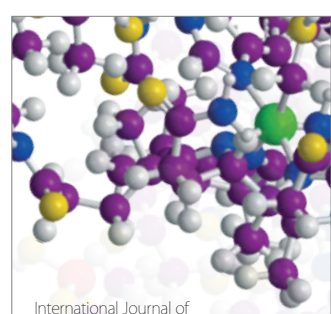

Carbohydrate Chemistry

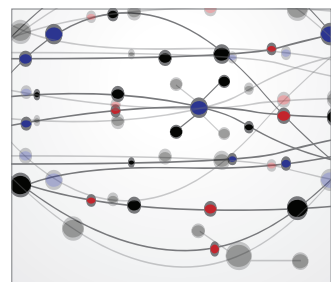

The Scientific World Journal
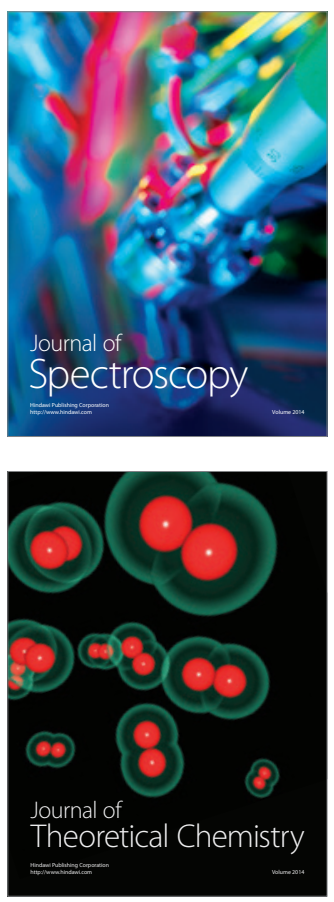
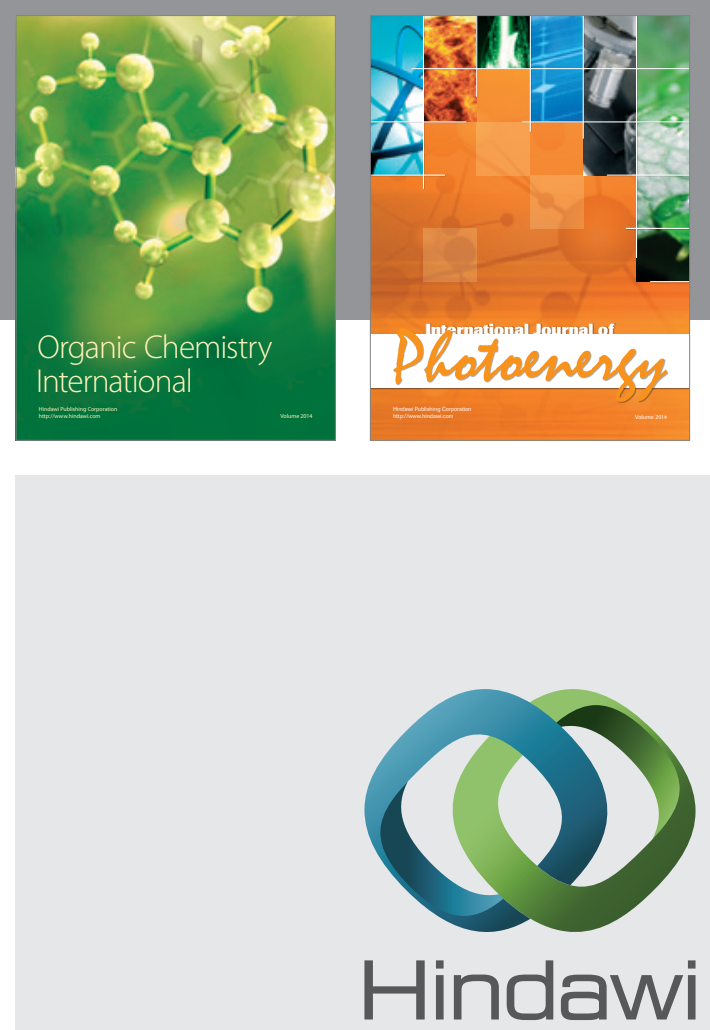

Submit your manuscripts at

http://www.hindawi.com
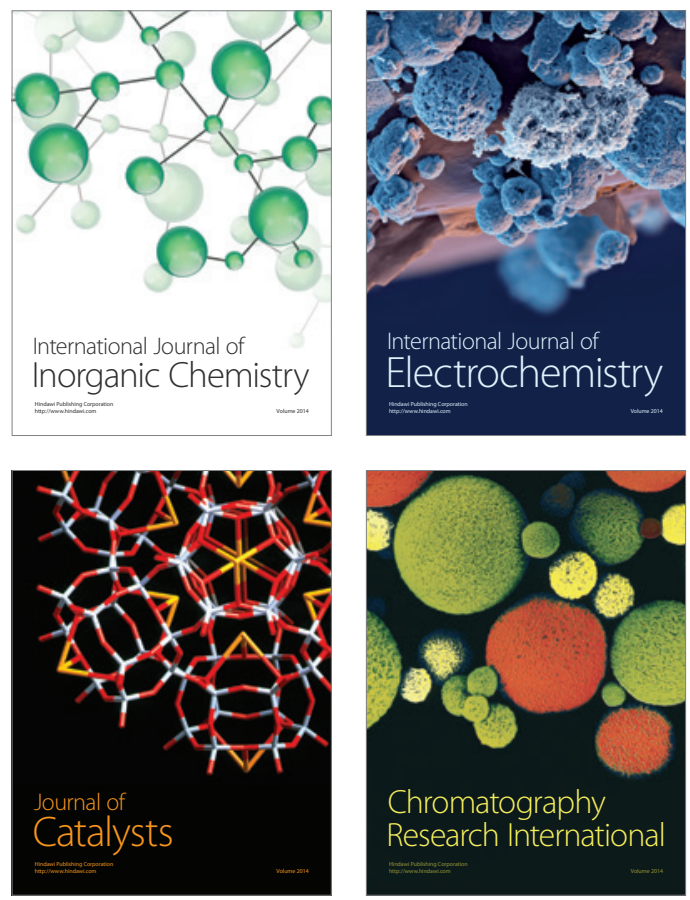
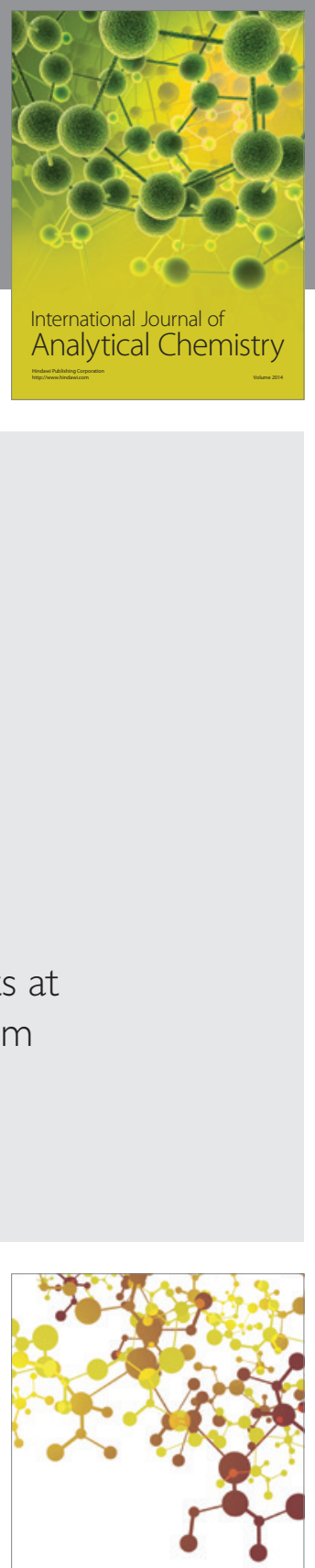

Journal of

Applied Chemistry
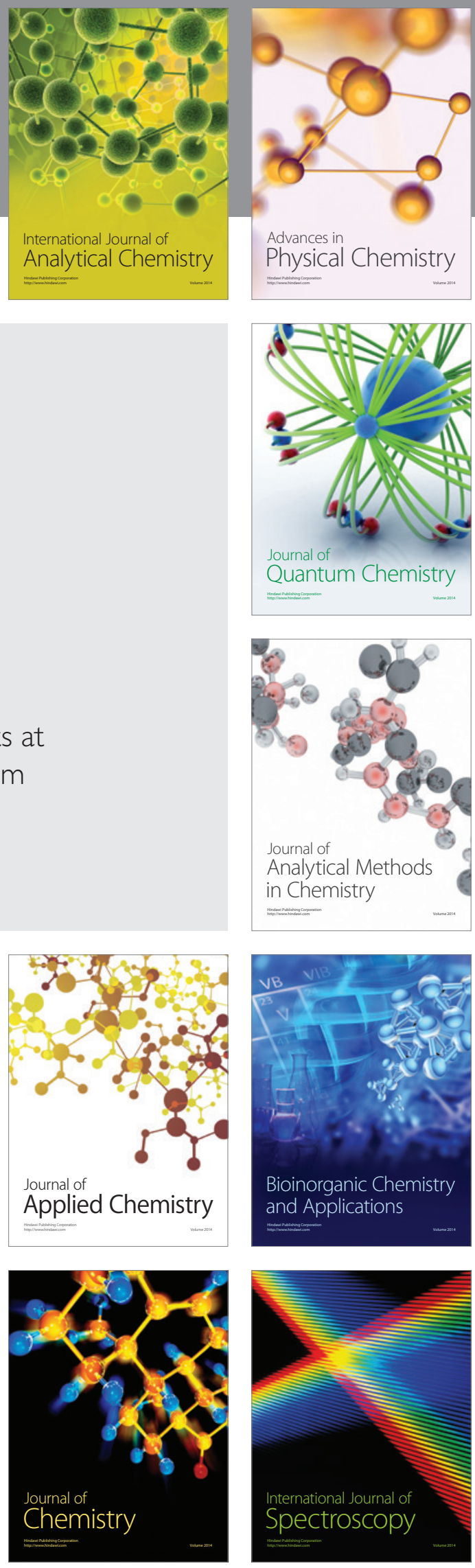